\title{
FEATURE
}

\section{Weeding with ADDIE Developing Training For Deselection At An Academic Library}

\section{J. Lindsay O’Neill}

J. Lindsay O'Neill (jloneill@exchange .fullerton.edu) is Instructional Design Librarian and Instruction Coordinator at California State University, Fullerton.
Reference \& User Services Quarterly, vol. 56, no. 2, pp. 108-15

(c) 2016 American Library Association. All rights reserved.

Permission granted to reproduce for nonprofit, educational use.
Weeding is a technically, emotionally, and politically difficult process for academic librarians, particularly when faced with a collection has not been weeded in years, if ever. Yet there is little research that examines how librarians can be supported in their deselecting activities with training. In this case study, a custom training resource enabled librarians at California State University, Fullerton, to more efficiently and confidently complete their weeding assignments. This paper describes a case study of use of instructional design model "ADDIE" (Analyze, Design, Develop, Implement, and Evaluate) to design and develop a training resource built on the LibGuide platform for librarians tasked with weeding their subject areas. Use of the ADDIE model encouraged librarian buy-in and resulted in the development of thoughtfully designed training that met librarians' needs and facilitated their success in weeding their subject areas. This paper fills a gap in the literature by describing a case study of using instructional design techniques and concepts to develop a local training resource on deselection.

ibrarians with weeding experience know how emotional and political weeding can be. It's common for community members to complain that that their local library is "throwing away" books in their collection, ${ }^{1}$ even though it's accepted practice to deselect books that are no longer worth the cost of storage and care. ${ }^{2}$ Tensions surrounding weeding projects only grow with the size of the project unless librarians take careful steps to communicate with patrons and stakeholders.

In this case study, Pollak Library at California State University, Fullerton (CSUF), began its first concerted weeding effort since the campus was opened in 1957. ${ }^{3}$ The library's print collection of 1.07 million volumes as of 2014 serves more than 37,000 students and thousands of faculty and staff. ${ }^{4}$ In 2014, fifteen librarians with collection development duties were assigned to weed their assigned subject areas over two years. Librarians had to learn how to use unfamiliar software to generate custom lists of items to consider for weeding, they had to make decisions over what should stay and what should go, and they had to communicate carefully with faculty members to help manage community response to this project. Pollak librarians have little experience with weeding due to lack of weeding activity at Pollak Library, and librarians' wide range of career backgrounds.

While there is extensive literature related to deselection, there is very 
little published on how individual institutions may support their librarians through this stressful process. This case study describes how an instructional design librarian used instructional design techniques and concepts to develop a local training resource on deselection. This resource guided librarians through the weeding workflow and supported them in the decision-making process. Following the ADDIE model of instructional design and developing "microlearning"-style demonstration videos and job aids resulted in a resource that met librarians' training needs and facilitated their success in weeding their subject areas.

\section{LITERATURE REVIEW}

\section{Weeding Emotions and Politics}

A literature review on the topic of weeding showed that removing material from a library is a political and emotional process. Librarians feel discomfort or guilt when deselecting materials and library patrons commonly show concern about weeding activities. ${ }^{5}$ Librarians also worry about making deselection mistakes, ${ }^{6}$ or admitting that they purchased items that they shouldn't have. ${ }^{7}$ Communication with and buy-in from stakeholders is essential to maintaining good community relations, and avoiding negative outcry. ${ }^{8}$ Weeding is a difficult and time-consuming process, but it is essential for libraries to remove outdated or unused materials and to create space for new materials. Furthermore, a properly weeded collection will increase circulation of the materials left behind because they are easier to find. ${ }^{9}$

There is little published literature on training librarians to weed. This may be because it's assumed that librarians learned enough about the process in library school, and manage to muddle through by consulting weeding texts like those published by Slote or that from the Arizona State Library. ${ }^{10}$ Ricchina and Vaccani stated that 50 percent of libraries involved in their weeding project at the Fondazione Per Leggere in Italy had no weeding experience. ${ }^{11}$ Thus they prepared a single document that contains weeding procedures and necessary tools, as well as administrative notes for librarians' reference. ${ }^{12}$ Similarly, Rich states that library staff was "largely young and inexperienced in the ways of massive weeding" at a Florida Law Library, so weeding criteria were developed and each volume to be weeded was reviewed by at least two people. ${ }^{13}$ There is little literature on how often libraries weed, but a wide-ranging 2003 deselection-focused survey of public librarians found that only about 32.7 percent of public libraries weed on an ongoing basis- the rest weed irregularly or every few years. ${ }^{14}$

Many, if not most, libraries avoid weeding their collections due to "lack of time, procrastination, fear of making a mistake, concern of being called a 'book burner,' and concern about dealing with opposition to such a project." ${ }^{15}$ A subset of respondents to the 2003 survey cited above reported that they would improve the weeding process, if they could, by implementing training "so as to make staff better understand the concepts behind weeding and the need for continuous evaluation and review of materials." ${ }^{\text {"6 }}$

Furthermore, there is a gap in the literature regarding the specific topics that deselection training should specifically cover. However, corporate training literature tackles the question of determining training scope: "What is the optimal amount of training in a given situation? The answer is clear: The optimal amount of training is the least that will get the job done."17 Librarians in North America generally hold a Master of Library and Information Science or similar degree, and most library schools cover weeding only in theory. ${ }^{18}$ Therefore, librarians are generally familiar with weeding theory, but may benefit from having access to institution-specific job aids that detail the weeding workflow or illuminate tasks. "A job aid is a chart, a list, a summary, a checksheet or something similar that helps a person to do a job or perform a function."19 At Pollak Library, weeding librarians received in-person training on using projectspecific software, but like most learners, would probably not remember many details from the session.

The trouble with training is that employees don't have photographic memories. The trainer presents information, the trainee tries to absorb as much as possible, and then months later, when some situation on the job makes the information truly relevant, the employee finds he has forgotten most of the details. That's when job aids come to the rescue. ${ }^{20}$

Furthermore, if librarians only work on weeding in short bursts due to lack of time, they may benefit from on-demand training designed as "microlearning," which is defined as "laser-focused lessons that can be completed in less than five minutes." ${ }^{21}$ The microlearning format builds off the science of how people learn. Training is more effective if the trainer avoids "information overload," particularly by breaking information down into smaller chunks and prioritizing the most important content, as discussed by Brecher Cook and Klipfel."22 Microlearning is "a method of training designed not only to fit how we naturally learn, but also to compete with the ever-increasing demands on our attention." ${ }^{23}$ Perfect for overworked librarians.

\section{THE INSTRUCTIONAL DESIGN PROCESS}

The ADDIE model of instructional design was chosen to design this weeding training because of its flexibility. Bell and Shank describe ADDIE as the basis of many popular instructional design models and define it as an acronym for:

Analysis - the process of defining what is to be learned

Design - the process of specifying how it is to be learned

Development-the process of authoring and producing learning materials

Implementation-the process of installing the instruction product in a real-world context

Evaluation-the process of determining the impact of the instruction $^{24}$ 


\section{FEATURE}

Wegener praises ADDIE as a flexible model that allows the designer to jump between phases as necessary. ${ }^{25}$ McGurr states that the ADDIE model is "not copyrighted or trademarked; therefore it is an inexpensive and flexible model to use and adapt." ${ }^{\prime 26}$ The ADDIE model is a useful guide for designing training for professional librarians due to its flexibility through the design and development process.

In conceiving this project, which was completed as a culminating project for a Master of Education in Educational Technology, the instructional design librarian (designer) envisioned a centralized resource like that mentioned by Ricchina and Vaccini that would function as a go-to document for learning about weeding workflow and related tasks. ${ }^{27}$ This resource was developed with the help and expertise of a subject matter expert (SME), in this case the head of Pollak Library's technical services department, who was responsible for overseeing the weeding project. A SME is defined as an individual "who can articulate, demonstrate, explain and validate the relevant content that people need to know to do their job."28

The SME coordinated all aspects of the Pollak weeding project, including delivering in-person training on the chosen weeding software and communicating with the rest of the campus community about the project. She was very helpful in discussing the weeding literature, with discussing potential topics for training, and on offering improvements to the completed training resource. At the initial meeting with the SME, the designer learned that librarians would receive in-person training to use specialized software called GreenGlass that was purchased to help librarians generate first-draft lists of potential weeds. This would be the only formal training for librarians related to weeding - they were instructed to use their own judgment for making weeding decisions. Weeded items would not be reviewed by other librarians, though campus faculty would have the opportunity to review and comment on items to be weeded before they are withdrawn. Such an open-ended directive certainly freed librarians to be as liberal or restrained in their weeding efforts as they wished, which fit with the spirit of academic freedom as librarians have faculty status at CSUF. However, the emotional component of weeding combined with the uncertainty of making the right decisions left many librarians wishing for greater direction.

\section{ANALYSIS}

Analysis is the first step in the instructional design model ADDIE. In the analysis phase, a designer surveys the target population or examines existing data to determine what training needs exist and which training format would best solve those needs. The analysis phase can be one of the longest in the overall design process because it's so important to determine what type of training is needed, if training is even needed at all. Using what was learned from the literature about deselection, the existing skills and disposition of the target population to receive training were examined. In Pollak Library's case, librarians had already received some training on the newly implemented weeding software. Thus a survey was administered to determine librarians' progress and attitudes in weeding, and which skills they might need help developing. By examining the literature, working with the SME, and surveying librarians, the designer identified training needs.

\section{The Weeding Process}

The weeding process at Pollak Library is simple on paper, as explained by the SME: weeding software produced by the company Sustainable Collection Services, called GreenGlass, was chosen to help librarians generate lists of items to consider for weeding. Pollak Library's entire catalog was batch uploaded into GreenGlass. Each librarian must log into the GreenGlass interface and generate subject-specific queries by number of check-outs and dates of usage, among other optional criteria. Completed queries are downloaded as Excel spreadsheet files, from which librarians may work to narrow down to final lists of items to be weeded. Subject librarians are also responsible for communicating about their weeding efforts to their respective subject faculty. Finally, faculty would be offered the chance to review and approve items to be weeded.

\section{Training Needs Survey}

Once the project scope was clear, a survey of Pollak Librarians was conducted to discover how librarians' training needs compared to those outlined in the literature. A secondary purpose of the survey was to include librarians in the design process so that they would be more likely to be aware of and turn to the training resource for help when needed. In the survey, librarians were asked to report their comfort level with weeding, as well as perceived obstacles to their weeding success, whether software, time or otherwise. The surveys for this case study were carried out with approval from the California State University, Fullerton, Institutional Review Board.

Eleven librarians responded to the survey, conducted in September 2014. More than half of respondents $(n=7)$ reported that they had not yet or had just started the weeding process. The rest reported being in the midst of weeding, but no one reported being almost done. Using a Likert Scale of 1-5, with 5 indicating Worry a lot and 1 No worry at all, librarians were across the board in their feelings of worry related to weeding (average $=2.6$ ). Respondents were largely concerned about finding the time to weed $(n=6)$, followed by Understanding the process/workflow $(n=4)$, and Mastering GreenGlass $(n=4)$. Librarians also indicated concern about managing external communication with stakeholders $(n=$ 3). The biggest challenge that respondents identified was finding the time to weed $(n=6)$.

However, librarians were fairly confident in their ability to weed their assigned sections. Reporting their feelings of 
confidence on a Likert scale from Not confident (1) to Very confident (5), librarians averaged 3.6. No one reported not feeling confident at all. Communication, both internal and external, was identified as a potential challenge by several respondents $(n=4)$.

\section{Analysis Conclusion}

This analysis shows that Pollak Librarians had many of the same concerns as detailed in the literature: having enough time, making the "right" decisions, and communicating about the project. They were also concerned about understanding the weeding workflow as well as using GreenGlass. No respondents indicated concern about using Microsoft Excel to manage their lists, however, librarians were just getting started in the weeding process and probably had not yet worked with large title lists in Excel. The provided training covered several somewhat advanced Excel functions including sorting data, filtering data, and cutting and pasting large amounts of content, which the SME noted that several librarians in the training struggled with. Providing a centralized resource with training resources for discrete tasks in the weeding process would be a good way to facilitate weeding success, and asynchronous on-demand training would be an appropriate format so that librarians could refer to it as their time allowed.

Faculty and staff on campus were also already concerned about what the library was "throwing away," and while weeding is necessary and done at every library across the world, stakeholders' perceptions complicate matters. To manage community concern, librarians have to perform careful public outreach. Therefore, featuring library talking points would be useful also in helping librarians communicate about weeding. Resources on managing time would also be useful.

\section{DESIGN}

Design is the second step in the ADDIE instructional design model. The bulk of design work for this project happened before actually developing the training, however, ADDIE allows the flexibility of jumping between phases as necessary, and the designer ended up coming back to the analysis and design phases multiple times. In the main design phase, the designer applied what she learned from the analysis phase to develop learning objectives, to outline content, and to consider needed technology/media.

A learning objective should be specific and measurable. The revised Bloom's Taxonomy was utilized to write the following objectives: ${ }^{29}$

Using the Weeding Training LibGuide, Pollak Librarians will be able to do the following:

- Select training/resources as needed for: GreenGlass, Microsoft Excel, weeding, and time management
- Explain the weeding project to faculty and interested community members

- Discuss case studies of other academic libraries' weeding projects

Once the learning objectives were complete, it was time to think about what kind of instructional content would facilitate librarians mastering the weeding process. The designer envisioned pulling together YouTube tutorials and creating job aids to direct librarians through the weeding workflow. A LibGuide was chosen as a satisfactory platform for this training resource. The tabbed design and mini-website format would be ideal for allowing librarians to access the resources they need quickly, or to simply browse. Also, librarians at Pollak already use LibGuides for a wide variety of subjects and are very familiar with the format. Media files are easily embeddable into LibGuides as well.

\section{Outlining Content}

As a librarian with limited time, the designer generally tries to avoid reinventing the wheel or to over-develop training. For this project, a LibGuide was adequate and it wasn't necessary to spend additional time developing a flashier, interactive tutorial. The designer also tries not to re-develop existing content. For this project, she was able to attend vendor-provided training for GreenGlass, and obtained her own log-in so that she could learn how it worked first-hand. There was already a selection of short tutorial videos available on the GreenGlass website that demonstrated a few key tasks. Plans were made to include these in the LibGuide, and also find similar tutorial videos for other topics. The designer wrote out a full outline of what content should be included based on what was learned in the analysis phase. The rough content outline included sections on getting help, GreenGlass, Microsoft Excel, Weeding resources, and time management resources (see figure 1).

At this point, a content outline was in place but no training had yet been developed. The LibGuide hadn't been created yet, let alone loaded with content, because it's common in the design phase to discover that the training as originally imagined isn't going to work in practice. It's far better to do as much design work as possible before spending time working on something that will end up unusable.

\section{Technology}

Fortunately, California State Fullerton has several educational technology tools perfect for developing this project. First, Pollak Library already uses LibGuides, which is a content management system that is popular among academic libraries. Many academic librarians use LibGuides regularly to create and digitally publish guides for research subjects, individual courses, and assignments. Second, the library had access to Camtasia thanks to a campus-wide license. Camtasia is video-editing software that is fairly easy to learn and also facilitates screen captures and recordings. 


\section{FEATURE}

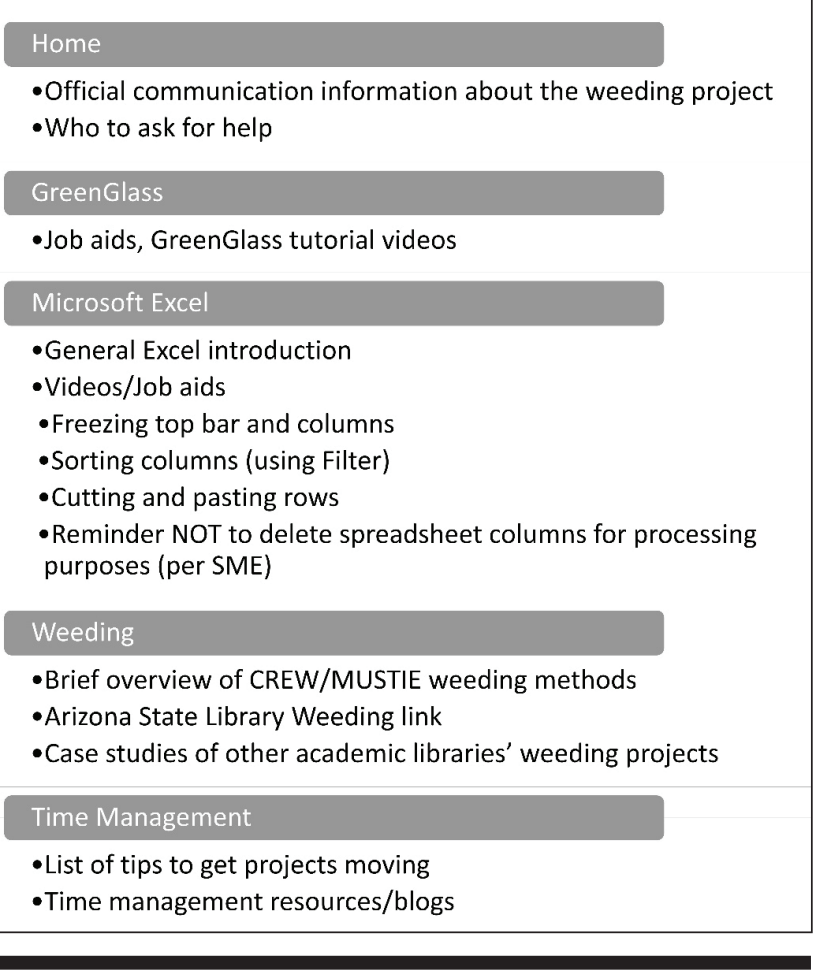

Figure 1. Content outline

\section{DEVELOPMENT}

The development phase is when the production of learning materials finally begins. A new LibGuide was created with five main pages based on the content outline: Home, GreenGlass, Microsoft Excel, Weeding Resources, and Making Time to Weed. The Home page was populated with basic information about the project and a simple project timeline (since removed, because the timeline kept changing and became less important). Most importantly, a box was created that listed the three main steps in the weeding workflow, and hyperlinked each step to relevant resources. This box was reused on each succeeding page so that librarians would know where they were in the process and what was next. A navigation box was also developed and posted to each page that listed these steps.

For specific task content, the designer sought out and embedded relevant tutorials. The full GreenGlass tutorial web page was embedded into the GreenGlass page. For Microsoft Excel tutorials, several relevant video tutorials were located on YouTube and embedded, but they ended up not being adequate for this project due to quality and lack of customization. The designer decided to record short screencasts on potentially difficult tasks in Excel, including freezing the top row of a spreadsheet, sorting and filtering by column, and deleting/adding rows and columns, based on what had been seen in the synchronous training provided. Each video is developed in the "microlearning" format: each is on a single topic and is less than two minutes long, and shows each step of a given task like a job aid. The LibGuide format allowed these videos to be embedded so that they are playable from within the guide itself.

On the Weeding Resources page, the basic weeding workflow was written out step-by-step, handful of links were included to reputable resources about how to weed, and a case study was included from a university that completed a weeding project on a similar scale. On the Making Time to Weed page, links were included to tips on project and time management.

\section{IMPLEMENTATION AND EVALUATION}

These two phases occurred virtually simultaneously. The implementation phase is when the training is rolled out to learners. In this case, that simply meant sending out an email to librarians with a brief explanation and link to the LibGuide. For this project, the implementation phase was the shortest phase because the provided training is asynchronous and online, so librarians could access it whenever convenient. The evaluation phase is key to having the necessary information to revise training to be maximally effective and useful.

\section{Formative Evaluation}

Formative assessment feedback was solicited from librarians and the SME so that changes could be made based on their opinions and needs. First, several librarians were approached at Pollak Library and asked to review the LibGuide's resources and to provide open-ended feedback. Based on their informal feedback, a few small changes were made, including redesigning the GreenGlass page to make the video content more easily navigable. Originally, the GreenGlass tutorial page was embedded, but it didn't list the videos available on the page. So, a navigation menu was created and placed at the top that described and linked to each video, so that librarians could see what was available at a glance.

The SME approved of the content, language, and resources that was used in the LibGuide, and suggested adding another video focused on the column-editing tools in Excel, which was then developed. With the SME's advice, more robust definitions of terms were developed that librarians would encounter on the GreenGlass website. Finally, another short video was created demonstrating a particular GreenGlass feature that combines queries, since the SME found that librarians didn't understand that particular function and weren't using it, even though it was a time-saving feature.

Once first round of feedback was incorporated into the LibGuide's training resources, an email was sent to all Pollak Librarians who had weeding duties to announce the LibGuide and request that they complete a brief, open-ended survey linked from the guide. Of a potential fifteen librarian respondents, four completed the survey, conducted in November 2014. The four responses to the feedback survey 
were positive. The survey asked for open-ended feedback for each of the tabs (with the exception of the Home tab) and for feedback on what the respondent considered the most useful and the least useful resource on the LibGuide. Respondents were also asked to rate the perceived usefulness of the LibGuide on a Likert scale of 1-5, with 5 being most useful.

For the GreenGlass tab, all four respondents stated that the tutorials were perfectly useful, with no more content needed. One respondent stated that he/she missed the inperson GreenGlass training, so the tutorials were especially helpful. For the Excel tab, all four respondents stated that the tutorials were adequate. One respondent stated that he/ she had "used Excel for years," so no additional tutorials were needed. Another respondent said that the tutorials were perfect for accessing at "point of need."

Several valuable responses were left by respondents describing what they found to be the most useful resource and the least useful resource on the LibGuide. The first respondent enjoyed the time management section most of all. Another respondent enjoyed the Excel and GreenGlass tutorials, but suggested that the LibGuide default to opening the linked articles into new windows, so that "I can find my way back to the guide." The four open-ended responses to the least useful resource question were almost all positive. One respondent stated that time management was least useful, and two said that the guide was adequate as is. The fourth respondent offered feedback on improving the wording of recommended talking points for communicating with faculty. Finally, when asked to rate the LibGuide's usefulness on a scale of $1-5$, with 5 being "Very useful," the guide was ranked an average of 4.25 .

\section{Jumping Back to Design/Development}

After reviewing these librarians' feedback and reflecting on the LibGuide's format, the Weeding Resources and Making Time to Weed pages were collapsed into a single Resources page for simplicity, but a new Add Your Own Resource page was created that had an embedded interactive virtual corkboard that allowed librarians to contribute to the LibGuide. A Weeding Interface page was also added by the SME's request that contained new job aids that were developed illustrating how to organize completed weeding lists in our library's custom web interface so that faculty could review them. The administrative backend of the weeding review webpage was programmed locally and required each librarian to log in and label each list of proposed weeding items with the relevant subject and call number range, and to also break them down into sub-lists as necessary. Breaking them down into subjectspecific lists would allow campus faculty to review them more easily. The "Guide on the Side" tutorial tool was used to create a walk-through tutorial on the administrative backend for librarians. A full job aid was also written describing the process for librarians to browse in the LibGuide or download as a PDF (see final LibGuide in figure 2).

\section{Summative Evaluation}

Almost a year after formatively assessing the training resource and making necessary changes, a final, summative, survey was conducted to measure how well librarians were served by the training. In October 2015, seven librarians out of fourteen potential participants (down from fifteen, as one librarian left in 2015) responded to the survey which solicited their opinions and self-reported use of the training. The majority of the respondents reported that they used the videos, and several stated that they liked having videos that broke down weeding tasks into short steps. Two librarians reported finding this LibGuide helpful for relearning how to do weeding-related tasks. One reported that he or she was glad to have the tutorials so she didn't have to "bug" anyone, and also to use as a "refresher, as I had long spans of time inbetween working on my weeding." Another librarian stated that he or she found it helpful to "just view short videos on the parts I was having trouble with." Four librarians found the Excel tutorials useful for learning to do small tasks within Excel (hiding columns, freezing rows). It is worth noting that in the initial analysis survey, librarians reported that they didn't need any help with Excel.

Statistics were also collected on how many visits the training resources received. The Weeding LibGuide, set to "private" and only accessible by having the link in hand, received 649 views from October 2014 to December 2015. The custom videos that were created on Excel and GreenGlass were hosted privately on YouTube and embedded in the private LibGuide, so the designer feels confident that the between nine and seventeen views that each video received were from librarians at Pollak Library.

\section{DISCUSSION}

Using the instructional design process ADDIE to guide development of the training was essential to ensure that the resulting product would be relevant and useful. Performing a thorough needs analysis of the target training population was indispensable to appropriately determine the scope of training. After doing an analysis of the weeding literature and surveying librarians, the SME and the designer believed that Pollak librarians would benefit from a selection of job aids and demonstration videos developed in the microlearning format. The librarians had received basic software training, but they had technical skill gaps that added to project difficulty. Also, because the weeding project would take two years to complete, librarians' skills and knowledge gained from in-person training would fade, so a centralized resource would serve as a useful, permanent reference.

The asynchronous format of this training was the right choice. In-person training was ideal for introducing librarians to the workflow steps and to give them a chance to discuss the work at hand and ask questions. But creating a centralized and static resource on weeding gave librarians a place to return as needed to refresh their knowledge. The 


\section{FEATURE}

\section{Pollak Library}

\section{RESEARCH SERVICES VISITING ABOUT GIVING}

Pollak Library / LibGuides / Weeding Training Resource / Home

\section{Weeding Training Resource: Home}

One-stop weeding training resource for Pollak Librarians.

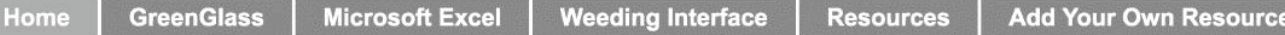

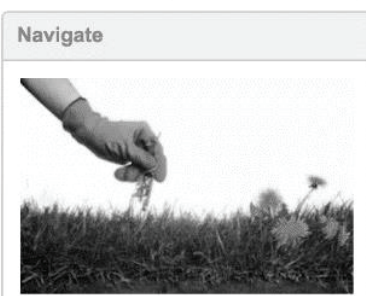

Guide Home

Step 1: GreenGlass

Step 2: Microsoft Excel

Step 3: Weeding

Interface

Resources

Add Your Own Resource

\section{URL}

Bookmark this link:

libraryguides.fullerton.edu/weeding

Weeding Workflow

Weeding workflow:

1. Generate lists in GreenGlass and export to Microsoft Excel

2. Finalize Excel spreadsheets of titles to be weeded

3. Set up list names and ranges in the Weeding Interface backend

Figure 2. Screenshot of final Weeding LibGuide. Source: http://libraryguides.fullerton.edu/weeding.

short video format worked well to demonstrate short tasks in GreenGlass and Excel, as librarians could play and replay them as needed. Using narration over a screen recording of a given task makes the topic clear and understandable, especially since each video was developed in a microlearning style: concise and focused on a single and specific topic. Also, as each librarian worked on weeding at his or her own pace as time allowed, developing bite-sized training fit allowed it to fit into every librarians' busy schedule, and the short format also facilitated learning through short chunks. Providing these tutorials online for anonymous use also allowed librarians to use them as often as desired while shielding them from feeling embarrassed if they didn't know how to do something.

The assessment data received from the surveys proved that the resource was valuable, but this project would not have been as successful without the help and guidance of the SME. Her collection development expertise and experience in training librarians to weed was hugely beneficial to developing a useful online resource. It was also fortunate that the library was able to rapidly deploy training via the LibGuide platform, and that the library had the screen recording software Camtasia.

This paper fills a gap in the weeding literature by describing the specifics of how librarians may be supported in their weeding activities by developing training in-house.
The implications of this case study are that the ADDIE instructional design process can be easily followed by other libraries to develop their own training, and that training can be developed cheaply using already available or free, readily available, software. The microlearning format is an excellent choice to develop "chunked" training that refreshes librarians' memories and also fits into any librarian's schedule. Developing videos is fairly easy using Camtasia, or by using a free alternative, like Jing. Jing limits recordings to five minutes, which is perfect for developing short videos. Furthermore, the training that was developed focused mainly on the technical skills that librarians would need to pull lists from GreenGlass and manipulate them in Microsoft Excel. There are many guides to weeding available, but the nitty-gritty work of manipulating large amounts of data with specialized tools is something that is best supported at a local, institutional level according to the target population's needs. Many academic libraries have the LibGuides platform or something similar and may use it to deploy training quickly and in an organized fashion.

\section{CONCLUSION}

Embarking upon the first major weeding project in the history of a large public university promised to be a major 
undertaking, but careful communication and a centralized on-demand training resource helped librarians be more successful in their deselection efforts. University library weeding projects like this are likely to occur more frequently as more libraries trend toward making more physical space available for student learning. Libraries undertaking similar weeding projects will benefit from not only providing in-person training for librarians on necessary software and resources, but from providing a static, on-demand training resource that librarians can refer to as needed.

The ADDIE model of instructional design can be easily followed by anyone looking to develop training. ADDIE is a very flexible model, but designers must take care to not skimp on the analysis phase, for it is in this phase that designers determine not only what training learners need, but if training is even needed at all. In this particular case study, providing a carefully designed and evaluated training resource proved useful to librarians. Whether planning to provide training for librarians assigned to weed, or for another in-house project altogether, the ADDIE model guides the design process in a time-efficient and thorough way. The ADDIE model can be easily followed to create useful resources for librarians and beyond.

\section{References}

1. Julie Goldberg, "I Can't Believe You're Throwing out Books!," Perfect Whole (blog), May 16, 2011, https://perfectwhole.wordpress .com/2011/05/16/i-cant-believe-youre-throwing-out-books.

2. Will Manley, "Treasure or Trash Heap?," American Libraries 45, no. 1 (2014): 80

3. Ann Roll, email message to author, November 21, 2014.

4. The California State University, "2013-2014 CSU Library Annual Statistic Report," CSU Library Statistic Reports, www.cal state.edu/library/content/statistics.

5. Terrance Luther Cottrell, "Weeding Worries, Part 1: Books," Bottom Line: Managing Library Finances 26, no. 3 (2013): 98; Mary Maguire, "If You Weed, They Will Come," One-Person Library 22, no. 12 (2006): 7; Elizabeth Murphy, "Assessing University Library Print Book Collections and Deselection: A Case Study at the National University of Ireland Maynooth," New Review of Academic Librarianship 19, no. 3 (2013): 256; Laura Raphael, "Killing Sir Walter Scott: A Philosophical Exploration of Weeding," In the Library with the Lead Pipe (July 24, 2013), www inthelibrarywiththeleadpipe.org/2013/killing-sir-walter-scott -a-philosophical-exploration-of-weeding; Stanley J. Slote, Weeding Library Collections: Library Weeding Methods (Englewood, CO: Libraries Unlimited, 1997), 5-6.

6. Mary Maguire, "If You Weed, They Will Come," One-Person Library 22, no. 12 (2006): 7-8; Diane J. Young, "Get to Effective Weeding," Library Journal 134, no. 19 (2009): 36.

7. Diane J. Young, "Get to Effective Weeding," Library Journal 134, no. 19 (2009): 36.

8. Elizabeth Murphy, "Assessing University Library Print Book Collections and Deselection: A Case Study at the National
University of Ireland Maynooth," New Review of Academic Librarianship 19, no. 3 (2013): 9-10; Carol A. Singer, "Weeding Gone Wild: Planning and Implementing a Review of the Reference Collection," Reference \& User Services Quarterly 47, no. 3 (2008): 262

9. "Collection Development Training: Weeding," Arizona State Library, Archives, and Public Records, accessed December 21, 2015, http://apps.azlibrary.gov/cdt/weeding.aspx; Stanley J. Slote, Weeding Library Collections: Library Weeding Methods (Englewood, CO: Libraries Unlimited, 1997), 5

10. Stanley J. Slote, Weeding Library Collections: Library Weeding Methods (Englewood, CO: Libraries Unlimited, 1997); "Collection Development Training: Weeding."

11. Laura Ricchina and Loredana Vaccani, "The Project of Coordinated Weeding for the Fondazione Per Leggere," Bibliothek Forschung und Praxis 36, no. 2 (2012): 250.

12. Ibid., 251-52.

13. Rebecca Rich, "Inch by Inch, Row by Row: A Tale of Two Major Weeding Projects," AALL Spectrum 18, no. 4 (2014): 6.

14. Juris Dilevko and Lisa Gottlieb, "Weed to Achieve: A Fundamental Part of the Public Library Mission?," Library Collections, Acquisitions, and Technical Services 27, no. 1 (2003): 78.

15. G. Edward Evans and Margaret Zarnosky Saponaro, Collection Management Basics (Santa Barbara, CA: Libraries Unlimited, 2012), 153

16. Dilevko and Gottlieb, "Weed to Achieve," 88.

17. Andrew Hubbard, "Determining the Scope of Training," Mortgage Banking 64, no. 10 (2004): 110.

18. Alison Shea, "It's Pracademic: Maximizing Efficiencies in the Library School Curriculum with Real World Projects," AALL Spectrum 12, no. 3 (2007): 22.

19. Andrew Hubbard, "Determining the Scope of Training," Mortgage Banking 64, no. 10 (2004): 110.

20. Nancy Chase, "Job Aids Help When Memory Fails," Quality 36, no. 12 (1997): 96

21. "Mi•Cro・Learn・Ing," TD: Talent Development 69, no. 3 (2015): 19.

22. Dani Brecher Cook and Kevin Michel Klipfel, "How Do Our Students Learn? An Outline of a Cognitive Psychological Model for Information Literacy Instruction," Reference \& User Services Quarterly 55, no. 1 (2015): 36.

23. "Mi•Cro•Learn・Ing," 19.

24. Steven J. Bell and John D. Shank, Academic Librarianship by Design (Chicago: ALA Editions, 2009), 42-43.

25. Debby R. Wegener, Training Library Patrons the Addie Way (Oxford: Chandos, 2006), 7.

26. Melanie McGurr, "Improving the Flow of Materials in a Cataloging Department: Using Addie for a Project in the Ohio State University Libraries," Library Resources \& Technical Services 52, no. 2 (2008): 55.

27. Laura Ricchina and Loredana Vaccani, "The Project of Coordinated Weeding for the Fondazione Per Leggere," Bibliothek Forschung und Praxis 36, no. 2 (2012): 251-52.

28. William W. Lee, "Subject Matter Experts and Instructional Designers: Making Distinctions," Performance + Instruction 33, no. 8 (2015): 24

29. Rex Heer, "A Model of Learning Objectives," Iowa State University Center for Excellence in Learning and Teaching, accessed December 21, 2015, www.celt.iastate.edu/teaching-resources/effective -practice/revised-blooms-taxonomy. 